\title{
Tumor cell PD-L1 expression is a strong predictor of unfavorable prognosis in immune checkpoint therapy-naive clear cell renal cell cancer
}

\author{
Katharina Möller ${ }^{1}$. Christoph Fraune ${ }^{1} \cdot$ Niclas C. Blessin $^{1} \cdot$ Maximilian Lennartz ${ }^{1}$. Martina Kluth ${ }^{1}$. \\ Claudia Hube-Magg ${ }^{1} \cdot$ Linnea Lindhorst ${ }^{1} \cdot$ Roland Dahlem $^{2} \cdot$ Margit Fisch $^{2} \cdot$ Till Eichenauer $^{2} \cdot$ Silke Riechardt $^{2}$. \\ Ronald Simon ${ }^{1}$ (1) . Guido Sauter ${ }^{1}$. Franziska Büscheck ${ }^{1}$. Wolfgang Höppner ${ }^{3}$. Cord Matthies ${ }^{4} \cdot$ Ousman Doh $^{5}$. \\ Till Krech ${ }^{1,6}$. Andreas H. Marx ${ }^{1,7} \cdot$ Henrik Zecha $^{8} \cdot$ Michael Rink $^{2} \cdot$ Stefan Steurer ${ }^{1}$. Till S. Clauditz ${ }^{1}$
}

Received: 5 February 2021 / Accepted: 17 March 2021 / Published online: 1 April 2021

(c) The Author(s) 2021

\begin{abstract}
Background PD-L1 expression predicts response to immune checkpoint inhibitors in renal cell carcinomas (RCC), but has also been suggested to be linked to poor patient outcome.

Methods We analyzed PD-L1 in > 1400 RCC in a tissue microarray format by immunohistochemistry. Results were compared with histological tumor type, parameters of cancer aggressiveness, and intratumoral CD $8^{+}$cytotoxic cells.

Result At a cut-off level of 5\% PD-L1 positive tumor cells, PD-L1 positivity was seen in $6.3 \%$ of 633 clear cell RCC (ccRCC), $18.2 \%$ of 165 papillary RCC, $18.8 \%$ of 64 chromophobe RCC, and $41.7 \%$ of 103 oncocytomas. In ccRCC, PD-L1 positivity was significantly linked to high ISUP $(p<0.0001)$, Fuhrman $(p<0.0001)$, Thoenes grade $(p<0.0001)$, distant metastasis $(p=0.0042)$, short recurrence-free $(p<0.0001)$, and overall survival $(p=0.0002)$. Intratumoral CD $8^{+}$lymphocytes were more frequent in PD-L1 positive (1055 \pm 109$)$ than in PD-L1 negative ccRCC $(407 \pm 28 ; p<0.0001)$. PD-L positive immune cells were seen in $8.2 \%$ of all RCC and $13.9 \%$ of papillary RCC. In ccRCC, PD-L1 positive immune cells were linked to high numbers of tumor-infiltrating CD8 ${ }^{+}$cells $(p<0.0001)$, high ISUP $(p<0.0001)$, Fuhrman $(p=0.0027)$, and Thoenes grade $(p<0.0001)$, and poor tumor-specific survival $(p=0.0280)$.
\end{abstract}

Conclusions These data suggest that PD-L1 expression in highly immunogenic RCCs facilitates immune evasion and contributes to cancer aggressiveness.

Keywords PD-L1 $\cdot$ Renal cell carcinoma $\cdot$ Immune checkpoint therapy $\cdot$ Prognosis

Ronald Simon

R.Simon@uke.de

1 Institute of Pathology, University Medical Center HamburgEppendorf, Martinistr. 52, 20246 Hamburg, Germany

2 Department of Urology, University Medical Center Hamburg-Eppendorf, Hamburg, Germany

3 Department of Urology, Itzehoe Medical Center, Itzehoe, Germany

4 Department of Urology, Bundeswehr Hospital Hamburg, Hamburg, Germany
5 Department of Urology, Regio Medical Center Elmshorn, Elmshorn, Germany

6 Institute of Pathology, Clinical Center Osnabrueck, Osnabrück, Germany

7 Department of Pathology, Academic Hospital Fuerth, Fuerth, Germany

8 Department of Urology, Albertinen Clinic, Hamburg, Germany 


\section{Introduction}

Renal cell carcinoma (RCC) is one of the most common cancer types worldwide [1]. Localized tumors are generally treated by total or partial nephrectomy. For patients in need for a systemic therapy, several new drugs have recently gained approval and improved the prognosis of metastatic RCC $[2,3]$. As in other cancer types, immune checkpoint inhibitors are in focus of current research [4-6]. In clear cell RCC, combinations of pembrolizumab (PD-1 inhibitor) and axitinib (VEGFR inhibitor), ipilimumab (CTLA-4 inhibitor) and nivolumab (PD-1 inhibitor), or avelumab (PD-L1 inhibitor) and axitinib showed superior survival as compared to standard therapies in phase III studies and are thus recommended and FDA approved as first-line systemic therapy in intermediate- and poor-risk patients [2, 7-10].

Clinical trials are currently investigating, whether adjuvant application of immune checkpoint inhibitors or other new drugs can improve the prognosis of kidney cancer patients at high risk for disease recurrence or progression after nephrectomy (Keynote-564, iMmotion010, Checkmate-914) [11]. If adjuvant treatment becomes standard of care, risk stratification will become more important than ever before, to enable optimal treatment decisions for individual patients. In this context, programmed cell death 1 ligand 1 (PD-L1) expression measurement is of particular interest. PD-L1 is one of the two programmed cell death 1 (PD-1) ligands and, thus, a part of an immune checkpoint system (PD-1/PD-L1) with widespread clinical application. PD-L1 expression-both on cancer cells and on tumor-infiltrating immune cells-predicts a favorable response to immune checkpoint inhibitors in various tumor types [12]. In RCC, several studies suggested that PD-L1 positivity is associated with a high number of tumor-infiltrating lymphocytes [13-20] and poor prognosis in cancers treated otherwise [15, 17, 19, 21-32]. A minority of studies came to different conclusions [20, 33-38]. The partially discrepant study results are likely to be caused by a lack of standardized procedures for PD-L1 measurement. Studies investigating PD-L1 expression by immunohistochemistry (IHC) have described positivity rates ranging from 5 to $57 \%$ for tumor cells [29, 39] and from 8 to $75 \%$ for immune cells [22, 40].

To generate more data on the potential prognostic role of PD-L1 expression in kidney cancer and its relationship with intratumoral lymphocytes, a cohort of 1476 RCC - all treated in the pre-immunotherapy era-was analyzed in a tissue microarray format (TMA) for PD-L1 expression on tumor cells and immune cells by IHC.

\section{Material and methods}

\section{Patients}

A set of TMAs was used containing one tissue core each from 1476 kidney tumors routinely diagnosed from nephrectomy specimen between 1994 and 2016 at the Institute of Pathology of the University Medical Center Hamburg-Eppendorf, Germany. All tumors had been reviewed according to the criteria described in the 2016 WHO classification by two pathologists with a special focus on genitourinary pathology (FB, CF) and ISUP (International Society of Urological Pathology) grading was performed for each tumor. Follow-up data were available for 531 of 808 clear cell RCC and 136 of 205 papillary RCC. Available study endpoint were overall survival, tumor-specific death, and recurrence-free survival, including patients without metastasis (M0) at the timepoint of surgery and patients with initial metastasis (M1) and additional progress after surgery. Density of $\mathrm{CD}^{+}$ cells measured by IHC was available in 1315 cases from a previous study [41]. The TMA comprises three blocks, which had been used earlier [42]. The TMA manufacturing process was described in detail before [43]. In brief, from each donor tumor, one tissue core measuring $0.6 \mathrm{~mm}$ in diameter was taken from a tumor-containing tissue block. Clinical and pathological parameters of the arrayed tumors are summarized in Table 1. The mean follow-up time was 48 months. The use of archived remnants of diagnostic tissues for manufacturing of TMAs and their analysis for research purpose as well as patient data analysis has been approved by local laws (HmbKHG, §12) and by the local ethics committee (Ethics Commission Hamburg, WF-049/09). All work has been carried out in compliance with the Helsinki Declaration.

\section{Immunohistochemistry (IHC)}

Freshly prepared TMA sections were immunostained on 1 day in one experiment. Slides were deparaffinized and exposed to heat-induced antigen retrieval for $5 \mathrm{~min}$ in an autoclave at $121{ }^{\circ} \mathrm{C}$ in pH9 Dako Target Retrieval Solution buffer (Agilent, CA, USA; \#S2367). Primary antibody specific against PD-L1 protein (mouse monoclonal, MS Validated Antibodies, Hamburg, Germany, clone MSVA-011) was applied at $37{ }^{\circ} \mathrm{C}$ for $60 \mathrm{~min}$ at a dilution of 1:150. Bound antibody was then visualized using the EnVision Kit ${ }^{\mathrm{TM}}$ (Agilent, CA, USA; \#K5007) according to the manufacturer's instructions. Membranous PD-L1 staining of the kidney tumor cells and immune cells was separately interpreted. In tumor cells, different cut-offs 
Table 1 Patient cohort

\begin{tabular}{|c|c|}
\hline & $\begin{array}{l}\text { Study cohort on TMA } \\
(n=1476)\end{array}$ \\
\hline Available $(n)$ & 848 \\
\hline Mean (months) & 62 \\
\hline Median (months) & 39 \\
\hline \multicolumn{2}{|l|}{ Age (years) } \\
\hline$<50$ & 202 \\
\hline $50-70$ & 384 \\
\hline $70-90$ & 729 \\
\hline \multicolumn{2}{|l|}{ Histology } \\
\hline Clear cell RCC & 808 \\
\hline Papillary RCC & 205 \\
\hline Chromophobe RCC & 81 \\
\hline Oncocytoma & 127 \\
\hline \multicolumn{2}{|l|}{ UICC stage } \\
\hline I & 559 \\
\hline II & 76 \\
\hline III & 113 \\
\hline IV & 102 \\
\hline \multicolumn{2}{|l|}{ pT category } \\
\hline $\mathrm{pT} 1$ & 728 \\
\hline pT2 & 150 \\
\hline pT3-4 & 277 \\
\hline \multicolumn{2}{|l|}{ ISUP grade } \\
\hline 1 & 329 \\
\hline 2 & 368 \\
\hline 3 & 298 \\
\hline 4 & 59 \\
\hline \multicolumn{2}{|l|}{ Fuhrman grade } \\
\hline 1 & 56 \\
\hline 2 & 636 \\
\hline 3 & 303 \\
\hline 4 & 68 \\
\hline \multicolumn{2}{|l|}{ Thoenes grade } \\
\hline 1 & 376 \\
\hline 2 & 594 \\
\hline 3 & 93 \\
\hline \multicolumn{2}{|l|}{$\mathrm{pN}$ category } \\
\hline pN0 & 174 \\
\hline $\mathrm{PN}+$ & 37 \\
\hline \multicolumn{2}{|l|}{ pM category } \\
\hline $\mathrm{pM} 0$ & 175 \\
\hline $\mathrm{pM}+$ & 97 \\
\hline
\end{tabular}

Numbers do not always add up to 1476 in the different categories because of missing data

based on the percentage of PD-L1 positive cells were used ( $\geq 1 \%, \geq 5 \%, \geq 10 \%$, and $\geq 50 \%$ ). In immune cells, PD-L1 staining were grouped in negative (no staining), few positive (few cells stained), and many positive (many cells stained). Density of $\mathrm{CD} 8^{+}$staining was evaluated in a previous study [41].

\section{PD-L1 antibody comparison}

To evaluate the staining properties of the used anti-PDL1 antibody MSVA-011 in comparison with the antiPD-L1 antibody E1L3N (rabbit monoclonal, Cell Signaling, Danvers, Massachusetts; \#13684)—which was most frequently used in earlier PD-L1 studies in kidney cancer-multiplex fluorescence IHC (mfIHC) was used. For mfIHC, the OPAL dye kit (Cat. \# NEL811001KT, AKOYA Biosciences, Menlo Park, California, United States) was used. The experimental procedure was mainly performed according to the manufacturer's instructions (AKOYA). Slides were initially boiled in an autoclave (30 min at $100-120{ }^{\circ} \mathrm{C}$ in $\mathrm{pH} 9$ buffer) for antigen retrieval. Antibodies to detect PD-L1 were stained sequentially and counterstained with diamidinoino-2-phenylindole (DAPI). One circle of antibody staining included peroxidase blocking, application of the first primary (MSVA-011) antibody, detection with a secondary HRP-conjugated antibody, fluorescence dye detection (Opal 570), and removal of the bound antibodies by microwave treatment $(4 \mathrm{~min}$ at $100{ }^{\circ} \mathrm{C}$ and $5 \mathrm{~min}$ at a mean temperature of $\left.93^{\circ} \mathrm{C}\right)$. This cycle was repeated for the second primary $(\mathrm{E} 1 \mathrm{~L} 3 \mathrm{~N}, \mathrm{pH}$, dilution 1:200) antibody and the second fluorescence dye (Opal 690). The same experiment was repeated with exchanged Opal dyes for both PD-L1 clones to ensure that the antibody comparison was independent from the used fluorochromes. Slides were mounted in antifade solution. Placenta and normal human tonsil samples were used as control tissue on every slide for the antibody comparison. Digital images of fluorescence stained slides were acquired with a Leica Aperio VERSA 8 automated epifluorescence microscope. Image analysis was performed using HALO $^{\text {TM }}$ software package (Indica Labs, USA) and included segmentation of individual cells (Supplementary Fig. 1A/B) to enable intensity measurements of PD-L1. The image analysis workflow has been described earlier [44]. To measure the co-expression of both anti-PD-L1 antibodies across 28 cancer microenvironments, the relationship between PD-L1 expression and density has been analyzed: correlation analysis of the PD-L1 expression level on individual cancer and immune cells revealed a high degree of co-expression $(r=0.929, p<0.0001$; Supplementary Fig. 1C). In addition, the number of PD-L1 positive inflammatory cells of both anti-PD-L1 clones was highly concordant in 28 representative cancer microenvironments $(r=0.941, p<0.0001$, Supplementary Fig. 1C). 


\section{Statistics}

Statistical calculations were performed with JPM 14 software (SAS Institute Inc, NC, USA) [45] and R version 3.6.1 (The $\mathrm{R}$ foundation) [46, 47]. The Pearson's correlation coefficient was used to measure the relationship between PD-L1 intensities and densities. Contingency tables and the Chi-square test were performed to search for associations between PD-L1 and tumor subtypes and tumor phenotype. ANOVA test was used to determine associations between PD-L1 immunostaining and $\mathrm{CD}^{+}$density. Survival curves were calculated according to Kaplan-Meier. The log-rank test was applied to detect significant survival differences between groups analysis of variance (ANOVA) tests were used to investigate the relationship between categorical and continuous data. A $p$ value $\leq 0.05$ was expected as statistically significant.

\section{Results}

\section{Technical issue}

PD-L1 expression on both tumor and immune cells was informative in 1036 (70.2\%) of 1476 arrayed cancers in our IHC analysis. Reasons of non-informative cases $(n=440$; $29.8 \%$ ) included lack of tissue samples or absence of unequivocal tumor cells in the TMA spot.

\section{PD-L1 expression in kidney tumors}

In normal kidney, PD-L1 expression was not observed. In tumor cells and tumor-infiltrating immune cells, PD-L1 expression-if present-was membranous. The staining pattern generated by the antibodies MSVA-011 and E1L3N was largely identical (Supplementary Fig. 1). Using different cut-off levels to define positivity in tumor cells, PD-L1 positivity was detected at comparable frequencies of $12.9 \%$ ( $\geq 1 \%$ positive cells), $12.9 \%$ ( $\geq 5 \%$ positive cells), $11.0 \%$ ( $\geq 10 \%$ positive cells), and $4.9 \%$ ( $\geq 50 \%$ positive cells) in
Fig. 1 PD-L1 expression in renal cell tumors. PD-L1 immunostaining is diffuse and strong in a clear cell RCC (a), shows a mosaic pattern in an oncocytoma (b), and - with a higher rate of positive cells-in a chromophobe carcinoma (c). A papillary RCC without tumor cell staining shows abundant PD-L1 positivity in tumorassociated macrophages located in the cores of papillae (d)
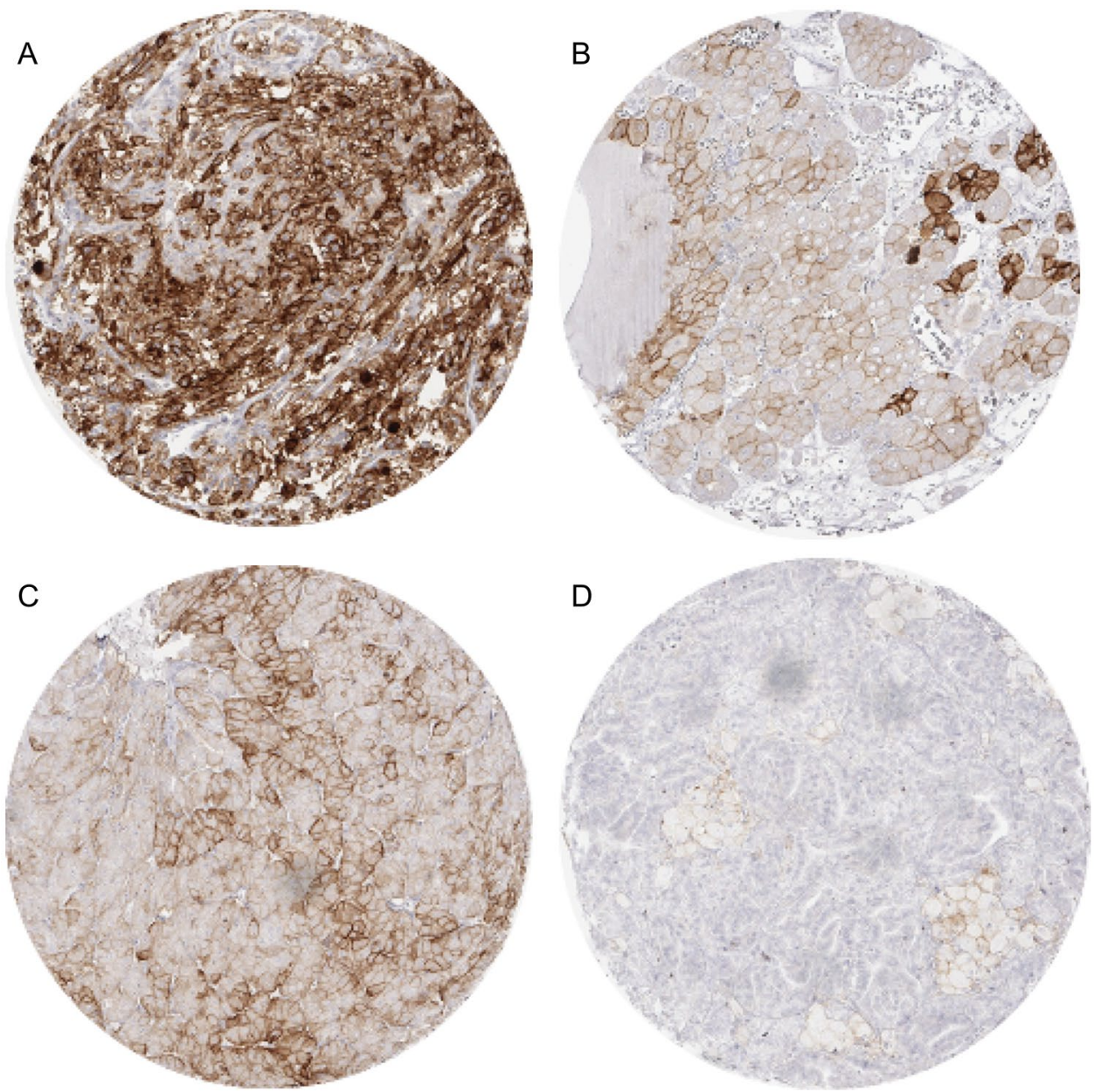
renal tumors. PD-L1 staining in tumor cells was often diffuse, sometimes focal within tumors and showed a mosaic pattern with a random appearing mixture of positive and negative cells. Representative images of PD-L1 positive tumors are given in Fig. 1. The frequency of PD-L1 expression varied between tumor subtypes. At a cut-off-level of $5 \%$ positive cells, PD-L1 expression in tumor cells was most commonly seen in oncocytomas $(41.7 \%)$, clearly less frequent in chromophobe (18.8\%) and papillary RCC (18.2\%), and even less frequent in clear cell RCC $(6.3 \%$, Supplementary Table 1). In immune cells, PD-L1 expression was seen in $8.2 \%$ of 1036 tumors with highest frequencies in papillary RCCs (13.9\%), followed by clear cell RCC (7.7\%), and oncocytomas (5.8\%, Supplementary Table 1).

\section{PD-L1 expression and tumor phenotype}

In clear cell RCC, PD-L1 expression in cancer cells and immune cells was related to adverse tumor features, including high ISUP $(p \leq 0.0010)$, high Fuhrmann $(p \leq 0.0030)$, and high Thoenes grade $(p \leq 0.0020)$ as well as short recurrence-free $(p<0.0001)$ and reduced overall survival $(p \leq 0.0030)$. This was largely regardless of the selected cut-off levels (Table 2, Fig. 2). In papillary RCCs, no association was found between PD-L1 expression and cancer phenotype or patient prognosis (Supplementary Fig. 2 and supplementary Table 2).

\section{PD-L1 expression and density of $\mathrm{CDB}^{+}$cells}

Data on both PD-L1 expression in tumor cells or immune cells and $\mathrm{CD} 8^{+}$cell density were available for 633 clear cell RCC and 165 papillary RCC. Irrespective of the used cutoff levels, the intratumoral $\mathrm{CD} 8^{+}$density was significantly higher in clear cell RCCs with PD-L1 positive cancer cells than in PD-L1 negative clear cell RCCs. Clear cell RCCs with PD-L1 positive immune cells had also higher intratumoral $\mathrm{CD}^{+}$cell counts than clear cell RCCs without PD-L1 positive immune cells $(p<0.0001)$. In papillary RCCs, an association between PD-L1 expression in tumor cells and $\mathrm{CD}^{+}$density was generally not found (except cut-off level 50\%). There was, however, a link between PD-L1 expression in immune cells and a high $\mathrm{CD} 8^{+}$density in papillary RCC $(p=0.0005$, Table 3$)$

\section{Discussion}

In this study, PD-L1 immunostaining varied significantly between kidney cancer subtypes. This fits well to the wellknown biological differences between different RCC subtypes (summarized in [48]). PD-L1 staining in tumor cells was significantly more frequent in papillary $(18 \%)$ and chromophobe (19\%), than in clear cell RCC (6\%). Only few studies have earlier studied multiple RCC subtypes [18, 24, $26,28,49,50]$ and the existing data on differences in PD-L1 expression between RCC subtypes are conflicting. Our observations are in line with studies that have also reported lower rates of PD-L1 positivity in clear cell compared to papillary $(0-16 \%$ vs $27-32 \%[18,26])$ or in chromophobe RCC ( $0 \%$ vs $35 \%$ [18]). However, there are also studies showing equally high or even higher PD-L1 positivity rates in clear cell RCCs than in other renal tumor subtypes [26, $28,49]$. Of note, oncocytomas, the benign counterpart of chromophobe RCC showed the highest rate of PD-L1 positivity (42\%) among the analyzed tumor subtypes. One earlier study had not found any PD-L1 expression in seven analyzed oncocytomas [18].

Clear cell RCC is the most common RCC subtype and has already been extensively analyzed for PD-L1 expression in earlier studies [14, 18-21, 25, 26, 28, 29, 31, 32, 35, 39, 40, $49,51]$. Our rate of 2-6\% PD-L1 positive clear cell RCCs (depending on the cut-off level to define PD-L1 positivity) is in the lower range of published data with PD-L1 positivity ranging from 0 to $77 \%$ in studies analyzing $34-756$ clear cell RCCs [14, 18-21, 25, 26, 28, 29, 31, 32, 35, 39, 40, 49, 51]. Reasons that are typically hold accountable for discrepant results in IHC studies include different antibodies, staining protocols, and criteria to define positivity. At least for RCC, the data do not suggest, that different binding properties of PD-L1 antibodies have led to the heterogeneous nature of existing data. 13 of the 33 earlier studies on PD-L1 in RCC have employed the antibody clone E1L3N, which shows highly similar staining properties as our antibody (Supplementary Fig. 1). These studies have described PD-L1 positivity to occur in $0-47 \%$ of clear cell RCC at a cut-off level of $1 \%$ or $5 \%$ stained cancer cells to define positivity [18, $19,25,28,32,35,49,51]$. The quantity of tissue analyzed per patient and difficulties in the distinction of interspeared PD-L1 positive macrophages that are interspersed between cancer cells from true PD-L1 positive cancer cells might also contribute to the data diversity of PD-L1 immunohistochemistry in the literature. Especially, if studies are considered that utilize cut-off levels of $1 \%$ or $5 \%$ to define PD-L1 positivity, the positivity rate is significantly higher in 14 studies using large sections (11-77\%; mean 28.9\%) than in nine studies using TMAs (4-29\%; mean 16.8\%; $p<0.0001)$ [13-26, 28-40, 49-54]. While these data might suggest that relevant PD-L1 findings are missed on TMAs, it is also possible that interpretation errors-such as mistaking macrophages for tumor cells-are more likely to occur on large sections. The only large-scale study comparing IHC findings obtained from TMAs and corresponding large sections with clinical outcome data was on p53 immunostaining in breast cancer [55]. Torhorst et al. found $15-21 \%$ p53 positivity on each of four TMAs made from a cohort of 553 breast cancers 


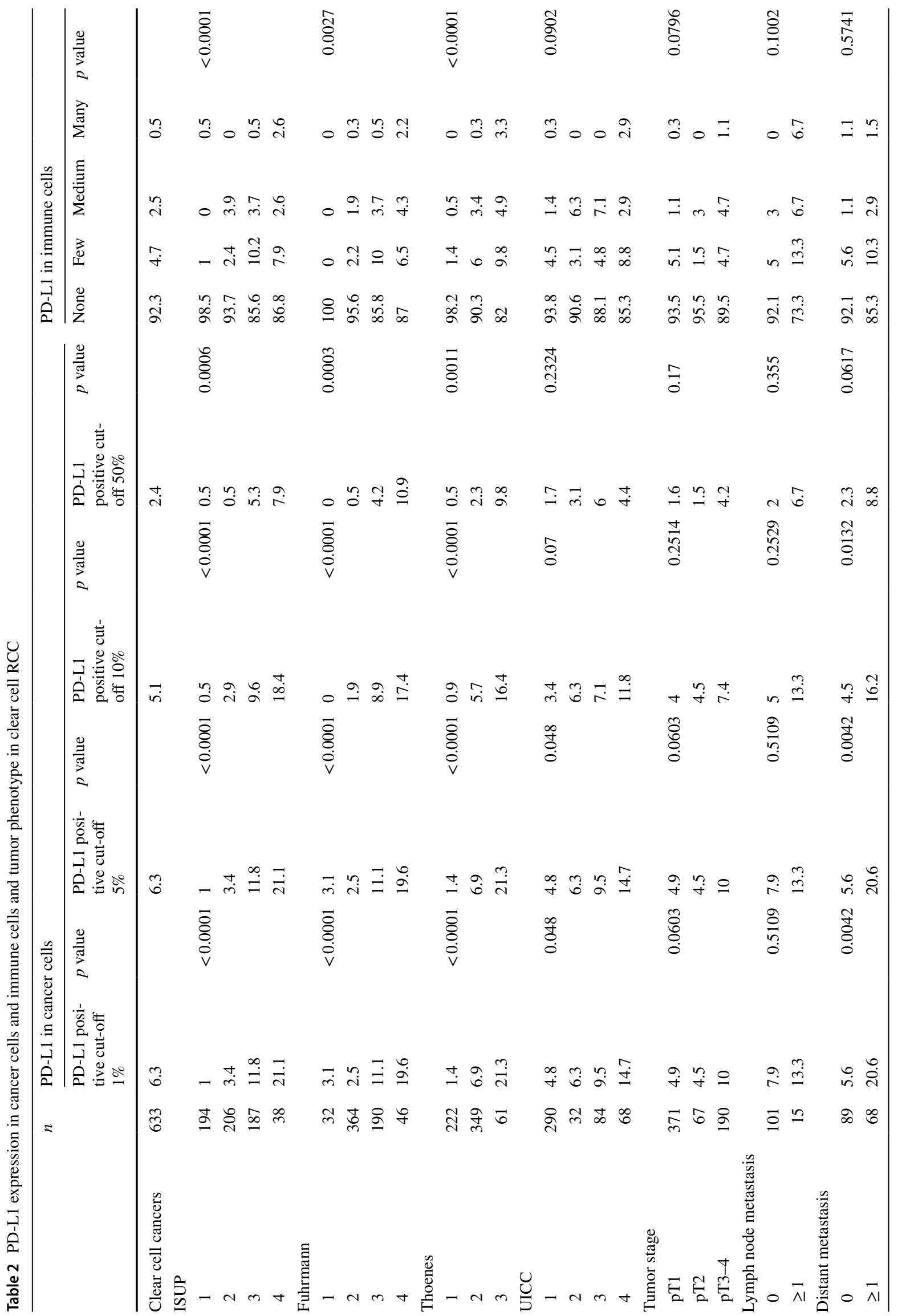




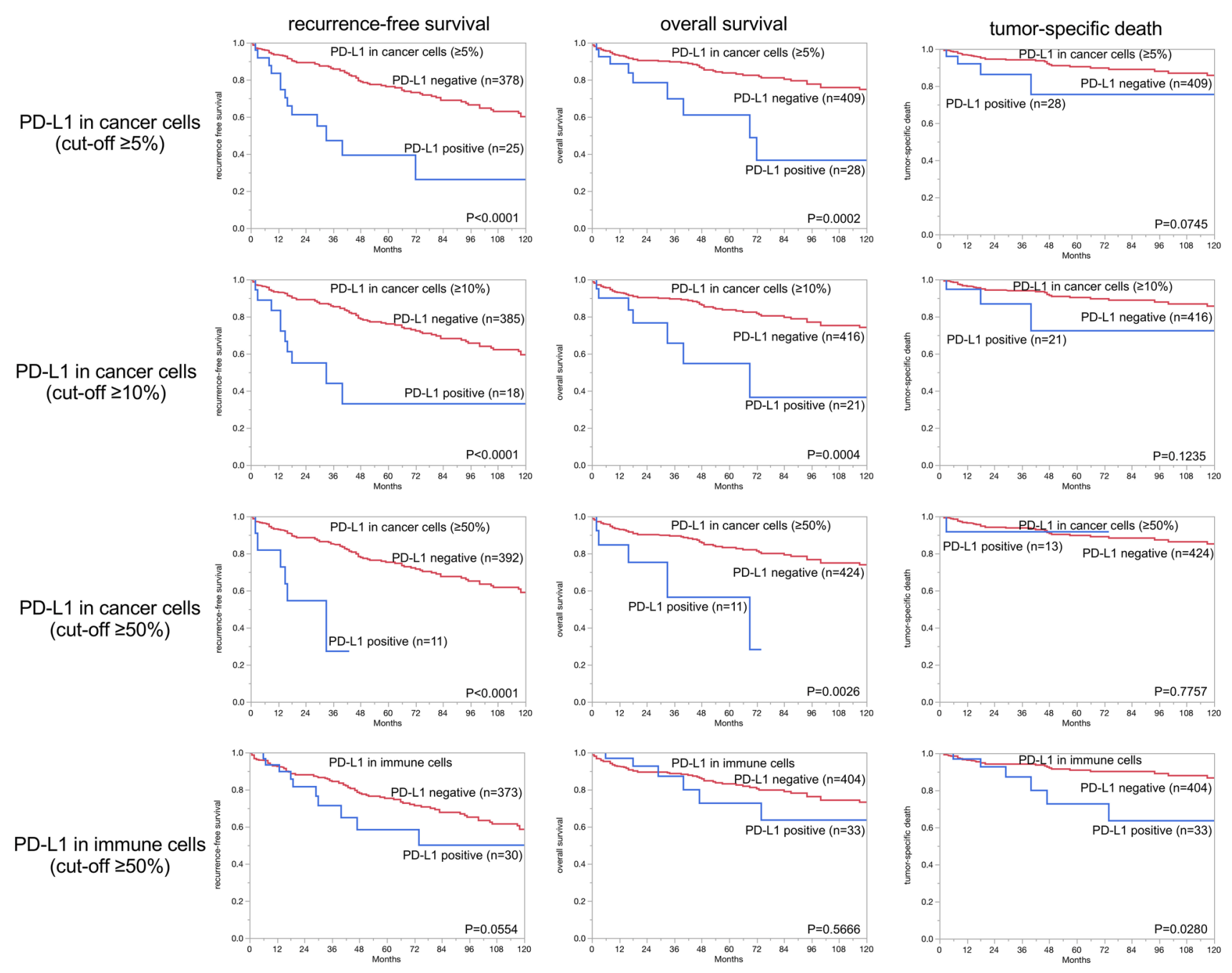

Fig. 2 PD-L1 expression in cancer cells and immune cells and patient prognosis in clear cell RCCs

but $43 \%$ positivity on large sections. As a link to patient survival was only seen for the p53 status obtained on the TMAs ( $p<0.0001$ each), but not for the large sections, it was concluded that prognostically irrelevant physiological or artificial p53 staining was overinterpreted on large sections but not on the TMAs.

PD-L1 positivity in tumor cells was strongly linked to unfavorable tumor phenotype and poor prognosis in this study. This was independent of the selected cut-offs and fits well with earlier data. 22 of 30 studies investigating the impact of PD-L1 expression on patient prognosis in 36-756 RCC patients have reported significantly worse outcomes in patients with PD-L1 positive tumors [13, 15, 19, 21-32, 39, $40,49-51,53]$. Both the known functions of PD-L1 and the particularly frequent PD-L1 expression in oncocytoma-the only benign tumor included in our study - argue against a direct role of PD-L1 expression for tumor progression. Data from several laboratories have previously described that a high number of tumor-infiltrating lymphocytes are linked to poor patient prognosis in $\mathrm{RCC}[38,41,56,57]$. This is in sharp contrast to the majority of other cancer types, such as colorectal cancer, non-small cell lung cancer, breast cancer, and melanoma where a high number of tumor-infiltrating lymphocytes-considered as evidence for a strong antitumoral immune response-are strongly linked to favorable patient outcome [58-64]. It is tempting to speculate that the inverse prognostic impact of tumor-infiltrating lymphocytes in RCC is evidence for particularly efficient anti-immune mechanisms in these tumors protecting RCC cells from $\mathrm{CD} 8^{+}$cytotoxic $\mathrm{T}$ cells. The striking association between PD-L1 expression in cancer cells and a high number of intratumoral $\mathrm{CD}^{+}$cytotoxic T-lymphocytes may suggest that PD-L1 overexpression is driven by a lymphocyte-rich microenvironment and constitutes one of the mechanisms allowing for immune evasion and further progression of highly immunogenic RCCs. 
Table 3 PD-L1 expression in cancer cells and immune cells and density of CD8 positive cells

\begin{tabular}{|c|c|c|c|c|c|c|}
\hline & \multicolumn{3}{|c|}{ Clear cell renal cell carcinomas } & \multicolumn{3}{|c|}{$\begin{array}{l}\text { Papillary renal cell carcino- } \\
\text { mas }\end{array}$} \\
\hline & $n$ & CD8 + density (cells $\left./ \mathrm{mm}^{2}\right)$ & $P$ & $n$ & $\begin{array}{l}\text { CD8 + density } \\
\left(\text { cells } / \mathrm{mm}^{2}\right)\end{array}$ & $p$ \\
\hline \multicolumn{7}{|l|}{ Tumor cells } \\
\hline \multicolumn{7}{|l|}{ PD-L1 cut-off $1 \%$} \\
\hline Negative & 593 & $407 \pm 28.4$ & $<0.0001$ & 135 & $219.9 \pm 73.5$ & 0.2539 \\
\hline Positive & 40 & $1055.2 \pm 109.3$ & & 30 & $317.9 \pm 79.6$ & \\
\hline \multicolumn{7}{|l|}{ PD-L1 cut-off $5 \%$} \\
\hline Negative & 593 & $407 \pm 28.4$ & $<0.0001$ & 135 & $219.9 \pm 73.5$ & 0.2539 \\
\hline Positive & 40 & $1055.2 \pm 109.3$ & & 30 & $317.9 \pm 79.6$ & \\
\hline \multicolumn{7}{|l|}{ PD-L1 cut-off $10 \%$} \\
\hline Negative & 601 & $411.8 \pm 28.2$ & $<0.0001$ & 137 & $216.8 \pm 37.2$ & 0.2320 \\
\hline Positive & 32 & $1127.8 \pm 122.3$ & & 28 & $325.3 \pm 82.4$ & \\
\hline \multicolumn{7}{|l|}{ PD-L1 cut-off $50 \%$} \\
\hline Negative & 618 & $436.3 \pm 28.4$ & 0.0079 & 155 & $213.4 \pm 34.5$ & 0.0111 \\
\hline Positive & 15 & $927.6 \pm 182.1$ & & 10 & $573.2 \pm 135.8$ & \\
\hline \multicolumn{7}{|l|}{ Immune cells } \\
\hline \multicolumn{7}{|l|}{ PD-L1 } \\
\hline Low (none + few) & 614 & $412.3 \pm 27.4$ & $<0.0001$ & 142 & $188.4 \pm 35.4$ & 0.0005 \\
\hline High (medium + many) & 19 & $1600.5 \pm 155.9$ & & 23 & $524.1 \pm 88.0$ & \\
\hline
\end{tabular}

Our rate of $8 \%$ of renal tumors with detectable PD-L1 positivity in tumor-associated immune cells is also in the lower range of the $6-75 \%$ reported in the literature [15, 22, 24, 26, 40, 51]. Whether PD-L1 expression is more relevant if it occurs in tumor cells or in immune cells is subject to intensive debate [65-67]. The significant but less striking prognostic role of PD-L1 in immune cells compared to tumor cells argues for a non-pivotal clinical role of PD-L1 expression on macrophages in RCCs that are not treated by immune checkpoint inhibitors. Given the significant association of PD-L1 positivity in immune cells with the number of tumor-infiltrating lymphocytes, it is possible that the amount of PD-L1 positive immune cells strongly depends on the amount of tumor-infiltrating lymphocytes in general, which is a well-known predictor of poor prognosis in RCC.

In summary, the data of this study demonstrate a strong link of PD-L1 expression in tumor cells with poor prognosis in RCC patients not treated with immune checkpoint inhibitors. The strikingly higher number of intratumoral $\mathrm{CD}^{+}$cytotoxic lymphocytes in PD-L1 positive compared to PD-L1 negative RCCs may suggest that PD-L1 overexpression is driven by a lymphocyte-rich microenvironment and reflects a pivotal component of the particularly efficient immune evasion mechanisms of RCCs.

Supplementary Information The online version contains supplementary material available at https://doi.org/10.1007/s11255-021-02841-7.
Acknowledgements We are grateful to Melanie Witt, Inge Brandt, Maren Eisenberg, Julia Ebner, and Sünje Seekamp for excellent technical assistance.

Author contributions $\mathrm{KM}, \mathrm{CF}, \mathrm{RS}, \mathrm{MK}, \mathrm{SM}, \mathrm{NCB}$, TSC, and CHM contributed to conception, design, data collection, data analysis, statistical analysis, and/or manuscript writing. KM, LL, FB, MK, ML, TK, and AHM performed IHC analysis and scoring. WH, CM, OD, HZ, RD, MR, and SR: conception and design, collection of samples. SS, TK, AHM, and ML: collection and pathology data analysis. MF, WW, GS, and TSC: study supervision.

Funding Open Access funding enabled and organized by Projekt DEAL.

Availability of data and materials All data generated or analyzed during this study are included in this published article [and its supplementary information files].

\section{Declarations}

Conflict of interests The Institute of Pathology of the UKE receives royalties on the sale of PD-L1 clone MSVA-011 from MS Validated Antibodies GmbH (owned by a family member of GS).

Ethical approval and consent to participate The usage of archived diagnostic left-over tissues for manufacturing of tissue microarrays, their analysis for research purposes, and patient data analysis has been approved by local laws (HmbKHG, §12,1) and by the local ethics committee (Ethics commission Hamburg, WF-049/09). All work has been carried out in compliance with the Helsinki Declaration. 
Open Access This article is licensed under a Creative Commons Attribution 4.0 International License, which permits use, sharing, adaptation, distribution and reproduction in any medium or format, as long as you give appropriate credit to the original author(s) and the source, provide a link to the Creative Commons licence, and indicate if changes were made. The images or other third party material in this article are included in the article's Creative Commons licence, unless indicated otherwise in a credit line to the material. If material is not included in the article's Creative Commons licence and your intended use is not permitted by statutory regulation or exceeds the permitted use, you will need to obtain permission directly from the copyright holder. To view a copy of this licence, visit http://creativecommons.org/licenses/by/4.0/.

\section{References}

1. Bray F, Ferlay J, Soerjomataram I, Siegel RL, Torre LA, Jemal A (2018) Global cancer statistics 2018: GLOBOCAN estimates of incidence and mortality worldwide for 36 cancers in 185 countries. CA Cancer J Clin 68(6):394-424. https://doi.org/10.3322/ caac. 21492

2. Motzer RJ, Escudier B, McDermott DF, Aren Frontera O, Melichar B, Powles T, Donskov F, Plimack ER, Barthelemy P, Hammers HJ, George S, Grunwald V, Porta C, Neiman V, Ravaud A, Choueiri TK, Rini BI, Salman P, Kollmannsberger CK, Tykodi SS, Grimm MO, Gurney H, Leibowitz-Amit R, Geertsen PF, Amin A, Tomita Y, McHenry MB, Saggi SS, Tannir NM (2020) Survival outcomes and independent response assessment with nivolumab plus ipilimumab versus sunitinib in patients with advanced renal cell carcinoma: 42-month follow-up of a randomized phase 3 clinical trial. J Immunother Cancer. https://doi. org/10.1136/jitc-2020-000891

3. Choueiri TK, Hessel C, Halabi S, Sanford B, Michaelson MD, Hahn O, Walsh M, Olencki T, Picus J, Small EJ, Dakhil S, Feldman DR, Mangeshkar M, Scheffold C, George D, Morris MJ (2018) Corrigendum to "Cabozantinib versus sunitinib as initial therapy for metastatic renal cell carcinoma of intermediate or poor risk (Alliance A031203 CABOSUN randomised trial): Progression-free survival by independent review and overall survival update" [Eur J Cancer 94 (May 2018) 115-125]. Eur J Cancer 103:287. https://doi.org/10.1016/j.ejca.2018.09.022

4. Addeo A, Banna GL, Metro G, Di Maio M (2019) Chemotherapy in combination with immune checkpoint inhibitors for the firstline treatment of patients with advanced non-small cell lung cancer: a systematic review and literature-based meta-analysis. Front Oncol 9:264. https://doi.org/10.3389/fonc.2019.00264

5. Katz H, Biglow L, Alsharedi M (2020) Immune checkpoint inhibitors in locally advanced, unresectable, and metastatic upper gastrointestinal malignancies. J Gastrointest Cancer 51(2):611-619. https://doi.org/10.1007/s12029-019-00243-8

6. Khair DO, Bax HJ, Mele S, Crescioli S, Pellizzari G, Khiabany A, Nakamura M, Harris RJ, French E, Hoffmann RM, Williams IP, Cheung A, Thair B, Beales CT, Touizer E, Signell AW, Tasnova NL, Spicer JF, Josephs DH, Geh JL, MacKenzie Ross A, Healy C, Papa S, Lacy KE, Karagiannis SN (2019) Combining immune checkpoint inhibitors: established and emerging targets and strategies to improve outcomes in melanoma. Front Immunol 10:453. https://doi.org/10.3389/fimmu.2019.00453

7. Ljungberg B, Albiges L, Abu-Ghanem Y, Bensalah K, Dabestani S, Fernandez-Pello S, Giles RH, Hofmann F, Hora M, Kuczyk MA, Kuusk T, Lam TB, Marconi L, Merseburger AS, Powles T, Staehler M, Tahbaz R, Volpe A, Bex A (2019) European Association of urology guidelines on renal cell carcinoma: The 2019 update. Eur Urol 75(5):799-810. https://doi.org/10.1016/j.eururo. 2019.02 .011
8. Rini BI, Plimack ER, Stus V, Gafanov R, Hawkins R, Nosov D, Pouliot F, Alekseev B, Soulieres D, Melichar B, Vynnychenko I, Kryzhanivska A, Bondarenko I, Azevedo SJ, Borchiellini D, Szczylik C, Markus M, McDermott RS, Bedke J, Tartas S, Chang YH, Tamada S, Shou Q, Perini RF, Chen M, Atkins MB, Powles T, Investigators K (2019) Pembrolizumab plus axitinib versus sunitinib for advanced renal-cell carcinoma. N Engl J Med 380(12):1116-1127. https://doi.org/10.1056/NEJMoa1816714

9. Choueiri TK, Motzer RJ, Rini BI, Haanen J, Campbell MT, Venugopal B, Kollmannsberger C, Gravis-Mescam G, Uemura M, Lee JL, Grimm MO, Gurney H, Schmidinger M, Larkin J, Atkins MB, Pal SK, Wang J, Mariani M, Krishnaswami S, Cislo P, Chudnovsky A, Fowst C, Huang B, di Pietro A, Albiges L (2020) Updated efficacy results from the JAVELIN Renal 101 trial: first-line avelumab plus axitinib versus sunitinib in patients with advanced renal cell carcinoma. Ann Oncol 31(8):1030-1039. https://doi.org/10.1016/j.annonc.2020.04.010

10. Vaddepally RK, Kharel P, Pandey R, Garje R, Chandra AB (2020) Review of indications of FDA-approved immune checkpoint inhibitors per NCCN guidelines with the level of evidence. Cancers (Basel). https://doi.org/10.3390/cancers12030738

11. Palumbo C, Mazzone E, Mistretta FA, Knipper S, Perrotte P, Shariat SF, Saad F, Kapoor A, Lattouf JB, Simeone C, Briganti A, Antonelli A, Karakiewicz PI (2019) A plea for optimizing selection in current adjuvant immunotherapy trials for highrisk nonmetastatic renal cell carcinoma according to expected cancer-specific mortality. Clin Genitourin Cancer. https://doi. org/10.1016/j.clgc.2019.11.010

12. Duffy MJ, Crown J (2019) Biomarkers for predicting response to immunotherapy with immune checkpoint inhibitors in cancer patients. Clin Chem 65(10):1228-1238. https://doi.org/10.1373/ clinchem.2019.303644

13. Basu A, Yearley JH, Annamalai L, Pryzbycin C, Rini B (2019) Association of PD-L1, PD-L2, and immune response markers in matched renal clear cell carcinoma primary and metastatic tissue specimens. Am J Clin Pathol 151(2):217-225. https://doi. org/10.1093/ajcp/aqy141

14. Eckel-Passow JE, Ho TH, Serie DJ, Cheville JC, Houston Thompson R, Costello BA, Dong H, Kwon ED, Leibovich BC, Parker AS (2020) Concordance of PD-1 and PD-L1 (B7-H1) in paired primary and metastatic clear cell renal cell carcinoma. Cancer Med 9(3):1152-1160. https://doi.org/10.1002/cam4. 2769

15. Flaifel A, Xie W, Braun DA, Ficial M, Bakouny Z, Nassar AH, Jennings RB, Escudier B, George DJ, Motzer RJ, Morris MJ, Powles T, Wang E, Huang Y, Freeman GJ, Choueiri TK, Signoretti S (2019) PD-L1 expression and clinical outcomes to cabozantinib, everolimus, and sunitinib in patients with metastatic renal cell carcinoma: analysis of the randomized clinical trials METEOR and CABOSUN. Clin Cancer Res 25(20):6080-6088. https://doi.org/10.1158/1078-0432.CCR-19-1135

16. Guo C, Zhao H, Wang Y, Bai S, Yang Z, Wei F, Ren X (2019) Prognostic value of the neo-immunoscore in renal cell carcinoma. Front Oncol 9:439. https://doi.org/10.3389/fonc.2019.00439

17. Kiyozawa D, Takamatsu D, Kohashi K, Kinoshita F, Ishihara S, Toda Y, Eto M, Oda Y (2020) Programmed death ligand 1/ indoleamine 2,3-dioxygenase 1 expression and tumor-infiltrating lymphocyte status in renal cell carcinoma with sarcomatoid changes and rhabdoid features. Hum Pathol 101:31-39. https:// doi.org/10.1016/j.humpath.2020.04.003

18. Walter B, Gil S, Naizhen X, Kruhlak MJ, Linehan WM, Srinivasan R, Merino MJ (2020) Determination of the expression of PD-L1 in the morphologic spectrum of renal cell carcinoma. $\mathrm{J}$ Cancer 11(12):3596-3603. https://doi.org/10.7150/jca.35738

19. Zhou QH, Li KW, Chen X, He HX, Peng SM, Peng SR, Wang Q, Li ZA, Tao YR, Cai WL, Liu RY, Huang H (2020) HHLA2 
and PD-L1 co-expression predicts poor prognosis in patients with clear cell renal cell carcinoma. J Immunother Cancer. https://doi. org/10.1136/jitc-2019-000157

20. Tatli Dogan H, Kiran M, Bilgin B, Kilicarslan A, Sendur MAN, Yalcin B, Ardicoglu A, Atmaca AF, Gumuskaya B (2018) Prognostic significance of the programmed death ligand 1 expression in clear cell renal cell carcinoma and correlation with the tumor microenvironment and hypoxia-inducible factor expression. Diagn Pathol 13(1):60. https://doi.org/10.1186/s13000-018-0742-8

21. Abbas M, Steffens S, Bellut M, Eggers H, Grosshennig A, Becker JU, Wegener G, Schrader AJ, Grunwald V, Ivanyi P (2016) Intratumoral expression of programmed death ligand 1 (PD-L1) in patients with clear cell renal cell carcinoma (ccRCC). Med Oncol 33(7):80. https://doi.org/10.1007/s12032-016-0794-0

22. Carlsson J, Sundqvist P, Kosuta V, Falt A, Giunchi F, Fiorentino M, Davidsson S (2020) PD-L1 expression is associated with poor prognosis in renal cell carcinoma. Appl Immunohistochem Mol Morphol 28(3):213-220. https://doi.org/10.1097/PAI.0000000000 000766

23. Chang K, Qu Y, Dai B, Zhao JY, Gan H, Shi G, Zhu Y, Shen Y, Zhu Y, Zhang H, Ye D (2017) PD-L1 expression in Xp11.2 translocation renal cell carcinoma: indicator of tumor aggressiveness. Sci Rep 7(1):2074. https://doi.org/10.1038/s41598-017-02005-7

24. Choueiri TK, Fay AP, Gray KP, Callea M, Ho TH, Albiges L, Bellmunt J, Song J, Carvo I, Lampron M, Stanton ML, Hodi FS, McDermott DF, Atkins MB, Freeman GJ, Hirsch MS, Signoretti $S$ (2014) PD-L1 expression in nonclear-cell renal cell carcinoma. Ann Oncol 25(11):2178-2184. https://doi.org/10.1093/annonc/ mdu445

25. Hong B, Cai L, Wang J, Liu S, Zhou J, Ma K, Zhang J, Zhou B, Peng X, Zhang N, Gong K (2019) Differential expression of PD-L1 between sporadic and VHL-associated hereditary clearcell renal cell carcinoma and its correlation with clinicopathological features. Clin Genitourin Cancer 17(2):97-104. https://doi.org/ 10.1016/j.clgc.2018.11.001

26. Lee HJ, Shin DH, Lee YJ, Lee SJ, Hwang CS, Kim A, Park WY, Lee JH, Choi KU, Kim JY, Lee CH, Sol MY, Park SW (2020) PD-L1 expression and infiltration by CD4(+) and FoxP3(+) T cells are increased in Xp11 translocation renal cell carcinoma and indicate poor prognosis. Histopathology 76(5):714-721. https:// doi.org/10.1111/his.14047

27. Shen M, Chen G, Xie Q, Li X, Xu H, Wang H, Zhao S (2020) Association between PD-L1 expression and the prognosis and clinicopathologic features of renal cell carcinoma: a systematic review and meta-analysis. Urol Int 104(7-8):533-541. https://doi. org/10.1159/000506296

28. Shin SJ, Jeon YK, Kim PJ, Cho YM, Koh J, Chung DH, Go H (2016) Clinicopathologic analysis of PD-L1 and PD-L2 expression in renal cell carcinoma: association with oncogenic proteins status. Ann Surg Oncol 23(2):694-702. https://doi.org/10.1245/ s10434-015-4903-7

29. Stenzel PJ, Schindeldecker M, Tagscherer KE, Foersch S, Herpel E, Hohenfellner M, Hatiboglu G, Alt J, Thomas C, Haferkamp A, Roth W, Macher-Goeppinger S (2020) Prognostic and predictive value of tumor-infiltrating leukocytes and of immune checkpoint molecules PD1 and PDL1 in clear cell renal cell carcinoma. Transl Oncol 13(2):336-345. https://doi.org/10.1016/j.tranon.2019.11. 002

30. Thompson RH, Kuntz SM, Leibovich BC, Dong H, Lohse CM, Webster WS, Sengupta S, Frank I, Parker AS, Zincke H, Blute ML, Sebo TJ, Cheville JC, Kwon ED (2006) Tumor B7-H1 is associated with poor prognosis in renal cell carcinoma patients with long-term follow-up. Cancer Res 66(7):3381-3385. https:// doi.org/10.1158/0008-5472.CAN-05-4303
31. Xiao WJ, Xu FJ, Zhang X, Zhou SX, Zhang HL, Dai B, Zhu Y, Shi GH, Shen YJ, Zhu YP, Qu YY, Zhao JY, Ye DW (2019) The prognostic value of programmed death-ligand 1 in a chinese cohort with clear cell renal cell carcinoma. Front Oncol 9:879. https://doi.org/10.3389/fonc.2019.00879

32. Yeong J, Zhao Z, Lim JCT, Li H, Thike AA, Koh VCY, Teh BT, Kanesvaran R, Toh CK, Tan PH, Khor LY (2020) PD-L1 expression is an unfavourable prognostic indicator in Asian renal cell carcinomas. J Clin Pathol 73(8):463-469. https://doi.org/10.1136/ jclinpath-2019-206092

33. Eich ML, Chaux A, Rodriguez MAM, Guner G, Taheri D, Rodriguez Pena MDC, Sharma R, Allaf ME, Netto GJ (2020) Tumour immune microenvironment in primary and metastatic papillary renal cell carcinoma. Histopathology 76(3):423-432. https://doi. org/10.1111/his. 13987

34. Erlmeier F, Hartmann A, Autenrieth M, Wiedemann M, Ivanyi P, Steffens S, Weichert W (2016) PD-1/PD-L1 expression in chromophobe renal cell carcinoma: an immunological exception? Med Oncol 33(11):120. https://doi.org/10.1007/s12032-016-0833-x

35. Jikuya R, Kishida T, Sakaguchi M, Yokose T, Yasui M, Hashizume A, Tatenuma T, Mizuno N, Muraoka K, Umemoto S, Kawai M, Yoshihara M, Nakamura Y, Miyagi Y, Sasada T (2020) Galectin-9 expression as a poor prognostic factor in patients with renal cell carcinoma. Cancer Immunol Immunother. https://doi.org/10. 1007/s00262-020-02608-6

36. Kim SH, Park WS, Park EY, Park B, Joo J, Joung JY, Seo HK, Lee KH, Chung J (2017) The prognostic value of BAP1, PBRM1, pS6, PTEN, TGase2, PD-L1, CA9, PSMA, and Ki-67 tissue markers in localized renal cell carcinoma: a retrospective study of tissue microarrays using immunohistochemistry. PLoS ONE 12(6):e0179610. https://doi.org/10.1371/journal.pone.0179610

37. Motoshima T, Komohara Y, Ma C, Dewi AK, Noguchi H, Yamada S, Nakayama T, Kitada S, Kawano Y, Takahashi W, Sugimoto M, Takeya M, Fujimoto N, Oda Y, Eto M (2017) PD-L1 expression in papillary renal cell carcinoma. BMC Urol 17(1):8. https://doi. org/10.1186/s12894-016-0195-x

38. Zhang S, Zhang E, Long J, Hu Z, Peng J, Liu L, Tang F, Li L, Ouyang Y, Zeng Z (2019) Immune infiltration in renal cell carcinoma. Cancer Sci 110(5):1564-1572. https://doi.org/10.1111/cas. 13996

39. Leite KR, Reis ST, Junior JP, Zerati M, Gomes Dde O, CamaraLopes LH, Srougi M (2015) PD-L1 expression in renal cell carcinoma clear cell type is related to unfavorable prognosis. Diagn Pathol 10:189. https://doi.org/10.1186/s13000-015-0414-x

40. Callea M, Albiges L, Gupta M, Cheng SC, Genega EM, Fay AP, Song J, Carvo I, Bhatt RS, Atkins MB, Hodi FS, Choueiri TK, McDermott DF, Freeman GJ, Signoretti S (2015) Differential expression of PD-L1 between primary and metastatic sites in clear-cell renal cell carcinoma. Cancer Immunol Res 3(10):11581164. https://doi.org/10.1158/2326-6066.CIR-15-0043

41. Eichenauer T, Simmendinger L, Fraune C, Mandelkow T, Blessin NC, Kluth M, Hube-Magg C, Moller K, Clauditz T, Weidemann S, Dahlem R, Fisch M, Riechardt S, Simon R, Sauter G, Buscheck F, Rink M (2020) High level of EZH2 expression is linked to high density of CD8-positive T-lymphocytes and an aggressive phenotype in renal cell carcinoma. World J Urol. https://doi.org/ 10.1007/s00345-020-03200-4

42. Buscheck F, Fraune C, Simon R, Kluth M, Hube-Magg C, MollerKoop C, Shadanpour N, Bannenberg C, Eichelberg C, Hoflmayer D, Clauditz T, Wittmer C, Wilczak W, Sauter G, Fisch M, Rink M, Eichenauer T (2018) Aberrant expression of membranous carbonic anhydrase IX (CAIX) is associated with unfavorable disease course in papillary and clear cell renal cell carcinoma. Urol Oncol 36(12):531 e519-531 e525. https://doi.org/10.1016/j.urolo nc. 2018.08 .015 
43. Kononen J, Bubendorf L, Kallioniemi A, Barlund M, Schraml P, Leighton S, Torhorst J, Mihatsch MJ, Sauter G, Kallioniemi OP (1998) Tissue microarrays for high-throughput molecular profiling of tumor specimens. Nat Med 4(7):844-847

44. Blessin NC, Spriestersbach P, Li W, Mandelkow T, Dum D, Simon R, Hube-Magg C, Lutz F, Viehweger F, Lennartz M, Fraune C, Nickelsen V, Fehrle W, Gobel C, Weidemann S, Clauditz T, Lebok P, Moller K, Steurer S, Izbicki JR, Sauter G, Minner S, Jacobsen F, Luebke AM, Buscheck F, Hoflmayer D, Wilczak W, Burandt E, Hinsch A (2020) Prevalence of CD8(+) cytotoxic lymphocytes in human neoplasms. Cell Oncol (Dordr) 43(3):421-430. https:// doi.org/10.1007/s13402-020-00496-7

45. SAS Institute Inc. 2018. JMP® 14 Documentation Library. SAS Institute Inc., Cary, NC

46. Tippmann S (2015) Programming tools: adventures with R. Nature 517(7532):109-110. https://doi.org/10.1038/517109a

47. R Core Team (2020) R: a language and environment for statistical computing. R Foundation for Statistical Computing, Vienna, Austria. http://www.R-project.org/

48. Inamura K (2017) Renal cell tumors: understanding their molecular pathological epidemiology and the 2016 WHO Classification. Int J Mol Sci. https://doi.org/10.3390/ijms18102195

49. Chandrasekaran D, Sundaram S, Kadhiresan N, Padmavathi R (2019) Programmed death ligand 1; an immunotarget for renal cell carcinoma. Asian Pac J Cancer Prev 20(10):2951-2957. https:// doi.org/10.31557/APJCP.2019.20.10.2951

50. Chipollini J, Azizi M, Peyton CC, Tang DH, Dhillon J, Spiess PE (2018) Implications of programmed death ligand-1 positivity in non-clear cell renal cell carcinoma. J Kidney Cancer VHL 5(4):6-13. https://doi.org/10.15586/jkcvhl.2018.107

51. Mikami S, Mizuno R, Kondo T, Shinohara N, Nonomura N, Ozono S, Eto M, Tatsugami K, Takayama T, Matsuyama H, Kishida T, Oya M, Japanese Society of Renal C (2019) Clinical significance of programmed death- 1 and programmed deathligand 1 expression in the tumor microenvironment of clear cell renal cell carcinoma. Cancer Sci 110(6):1820-1828. https://doi. org/10.1111/cas.14019

52. Labriola MK, Zhu J, Gupta R, McCall S, Jackson J, Kong EF, White JR, Cerqueira G, Gerding K, Simmons JK, George D, Zhang T (2020) Characterization of tumor mutation burden, PD-L1 and DNA repair genes to assess relationship to immune checkpoint inhibitors response in metastatic renal cell carcinoma. J Immunother Cancer. https://doi.org/10.1136/jitc-2019-000319

53. Chipollini J, da Costa WH, da Cunha IW, de Almeida EPF, Guilherme OSP, Azizi M, Spiess PE, Abreu D, Zequi SC (2019) Prognostic value of PD-L1 expression for surgically treated localized renal cell carcinoma: implications for risk stratification and adjuvant therapies. Ther Adv Urol 11:1756287219882600. https://doi. org/10.1177/1756287219882600

54. Joseph RW, Millis SZ, Carballido EM, Bryant D, Gatalica Z, Reddy S, Bryce AH, Vogelzang NJ, Stanton ML, Castle EP, Ho TH (2015) PD-1 and PD-L1 expression in renal cell carcinoma with sarcomatoid differentiation. Cancer Immunol Res 3(12):1303-1307. https://doi.org/10.1158/2326-6066. CIR-15-0150

55. Torhorst J, Bucher C, Kononen J, Haas P, Zuber M, Kochli OR, Mross F, Dieterich H, Moch H, Mihatsch M, Kallioniemi OP, Sauter G (2001) Tissue microarrays for rapid linking of molecular changes to clinical endpoints. Am J Pathol 159(6):2249-2256. https://doi.org/10.1016/S0002-9440(10)63075-1

56. Rozsypalova A, Rosova B, Filipova A, Nikolov DH, Chloupkova R, Richter I, Proks J, Zachoval R, Matej R, Melichar B, Buchler T, Dvorak J (2019) Negative prognostic significance of primary cilia,
CD8+ tumor infiltrating lymphocytes and PD1+ cells expression in clear cell renal cancer. J BUON 24(4):1644-1651

57. Giraldo NA, Becht E, Vano Y, Petitprez F, Lacroix L, Validire P, Sanchez-Salas R, Ingels A, Oudard S, Moatti A, Buttard B, Bourass S, Germain C, Cathelineau X, Fridman WH, SautesFridman C (2017) Tumor-infiltrating and peripheral blood T-cell immunophenotypes predict early relapse in localized clear cell renal cell carcinoma. Clin Cancer Res 23(15):4416-4428. https:// doi.org/10.1158/1078-0432.CCR-16-2848

58. Hanke T, Melling N, Simon R, Sauter G, Bokemeyer C, Lebok P, Terracciano LM, Izbicki JR, Marx AH (2015) High intratumoral FOXP3(+) T regulatory cell (Tregs) density is an independent good prognosticator in nodal negative colorectal cancer. Int J Clin Exp Pathol 8(7):8227-8235

59. Governa V, Trella E, Mele V, Tornillo L, Amicarella F, Cremonesi E, Muraro MG, Xu H, Droeser R, Daster SR, Bolli M, Rosso R, Oertli D, Eppenberger-Castori S, Terracciano LM, Iezzi G, Spagnoli GC (2017) The interplay between neutrophils and CD8(+) $\mathrm{T}$ cells improves survival in human colorectal cancer. Clin Cancer Res 23(14):3847-3858. https://doi.org/10.1158/1078-0432. CCR-16-2047

60. Jifu E, Yan F, Kang Z, Zhu L, Xing J, Yu E (2018) CD8(+) CXCR5(+) T cells in tumor-draining lymph nodes are highly activated and predict better prognosis in colorectal cancer. Hum Immunol 79(6):446-452. https://doi.org/10.1016/j.humimm.2018. 03.003

61. Kong JC, Guerra GR, Pham T, Mitchell C, Lynch AC, Warrier SK, Ramsay RG, Heriot AG (2019) Prognostic impact of tumorinfiltrating lymphocytes in primary and metastatic colorectal cancer: a systematic review and meta-analysis. Dis Colon Rectum 62(4):498-508. https://doi.org/10.1097/DCR.0000000000001332

62. Schalper KA, Brown J, Carvajal-Hausdorf D, McLaughlin J, Velcheti V, Syrigos KN, Herbst RS, Rimm DL (2015) Objective measurement and clinical significance of TILs in non-small cell lung cancer. J Natl Cancer Inst. https://doi.org/10.1093/jnci/ dju435

63. Mahmoud SM, Paish EC, Powe DG, Macmillan RD, Grainge MJ, Lee AH, Ellis IO, Green AR (2011) Tumor-infiltrating CD8+ lymphocytes predict clinical outcome in breast cancer. J Clin Oncol 29(15):1949-1955. https://doi.org/10.1200/JCO.2010.30.5037

64. Dudley ME, Yang JC, Sherry R, Hughes MS, Royal R, Kammula U, Robbins PF, Huang J, Citrin DE, Leitman SF, Wunderlich J, Restifo NP, Thomasian A, Downey SG, Smith FO, Klapper J, Morton K, Laurencot C, White DE, Rosenberg SA (2008) Adoptive cell therapy for patients with metastatic melanoma: evaluation of intensive myeloablative chemoradiation preparative regimens. $\mathrm{J}$ Clin Oncol 26(32):5233-5239. https://doi.org/10.1200/JCO.2008. 16.5449

65. Trimble P, Walleck C (1988) Trauma nursing: past, present, and future. Md Med J 37(7):547-550

66. Chen DS, Mellman I (2017) Elements of cancer immunity and the cancer-immune set point. Nature 541(7637):321-330. https://doi. org/10.1038/nature21349

67. Chen DS, Mellman I (2013) Oncology meets immunology: the cancer-immunity cycle. Immunity 39(1):1-10. https://doi.org/10. 1016/j.immuni.2013.07.012

Publisher's Note Springer Nature remains neutral with regard to jurisdictional claims in published maps and institutional affiliations. 